\title{
Congressional Fellowship Alumni Gather to Honor Lee Hamilton
}

\section{Jeffrey R. Biggs, APSA Congressional Fellowship Program}

Following his packed-room Pi Sigma Alpha Guest Lecture, "What I Wish Political Scientists Would Teach about Congress," former member of the House of Representatives (1964-98) and current director of the Woodrow Wilson International Center for Scholars, Lee Hamilton moved on to another standingroom-only audience.

It has been traditional in recent years for Congressional Fellowship Program alumni to gather when the Annual Meeting is held in Washington, DC. This year, some 120 former Fellows, including political scientists from all fields, practicing journalists, government-employed domestic and foreign policy specialists, Robert Wood Johnson health policy fellows, international scholars whose CFP years were sponsored by the German Marshall Fund of the United States and Ford Foundation, and a Native American tribal representative who had served as a Hatfield Fellow, came together to honor Lee Hamilton at the Pi Sigma Alpha-CFP reception.

To a person, Congressional Fellows have always regarded their year working as a congressional staffer as pivotal to their subsequent careers and they lay much of the credit to the individual for whom they worked on the Hill. Lee Hamilton was honored in that spirit. Until his retirement in 1998, he stood in a class of his own as he guided Fellows through the congressional laby-

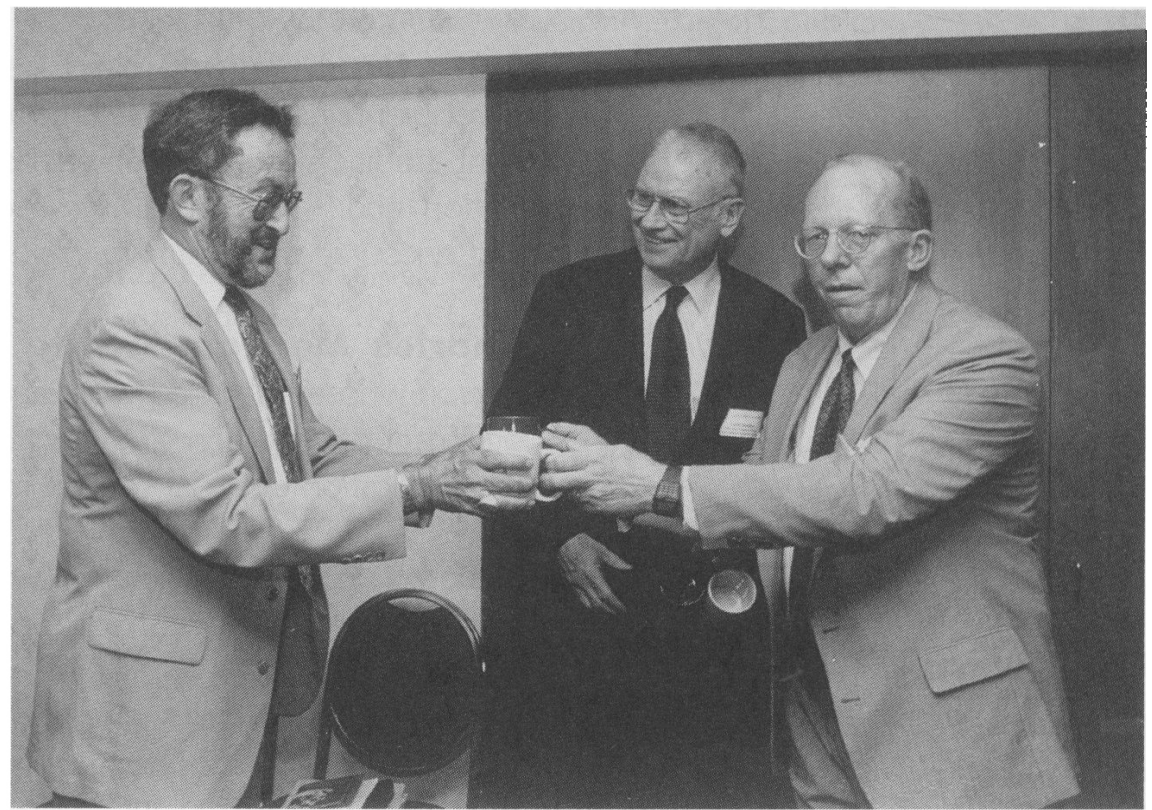

Congressional Fellowship Program Director Jeff Biggs, (r) an 1984-85 Congressional Fellow, presents Pi Sigma Alpha and CFP coffee mugs to Stephen Wasby (I) and Lee Hamilton (center). tion that a Fellow try Hamilton's office that led him or her to seek placement there.

What was it that Lee Hamilton gave to the Fellows in this program which is still so highly valued? As the current director of the program, I reviewed for the reception guests the comments of former Congressional Fellows who had worked for Hamilton. "In Lee Hamilton's office," observed a former Fellow, "there was no hand-holding. A Fellow was regarded as a professional and expected to carry out the work with a minimum of guidance. He made a point of including the Congressional Fellow in office staff meetings and political strategy sessions, and frequently invited staff to join him for lunch in the House restaurant." A Fellow from the 1970s recounted a whirlwind Indiana district visit with Hamilton: "In 48 hours, we visited two county fairs, a poor people's caucus, a VJ-Day parade, a wine festival, an electrical cooperative meeting, a Catholic school fair, and two Democratic rallies."

During those years, Congressional Fellows had the rare opportunity of working on both Hamilton's personal and international relations committee staff. The week began every Monday with a personal office staff meeting at 9:00 a.m. and an IR committee staff meeting at 9:30. Substantive interaction with Lee Hamilton usually began with a short one-page memo in bullet form. In many cases, the memo came back within a few hours with "Talk to me" scribbled on the margin. At a committee staff party not long before Hamilton retired, some staffers put on a little spoof titled "'Talk to Me': Or How Congress Makes Foreign Policy." Lee Hamilton seemed to laugh the hardest.

\section{Congressional Fellow Alumnus Stephen Wasby Honors Hamilton}

Most of the Fellows who served in Lee Hamilton's office joined other CFP colleagues as participants in 
the two-decades-old APSA Congressional FellowsCanadian Parliamentary Interns Exchange, which has provided a remarkable in-depth comparative government experience for several hundred Fellows. However, as described in a recent CFP alumni letter, the funding for this relatively inexpensive week's visit to Ottawa has been threatened in recent years as the major sponsors of the program, the U.S. Information Agency and, later, the U.S. Department of State, cut back on their educational and cultural affairs grants.

Unwilling to let the parliamentary exchange remain in jeopardy, SUNY-Albany Professor Stephen Wasby, a 1965-66 Congressional Fellow and an authority on the federal court system, chose his own way of honoring Lee Hamilton. Speaking to Lee Hamilton and the reception antendees, Professor Wasby noted that "the Congressional Fellowship Program . . . was an important part of my professional career, a year on which I look back with great pleasure. An important part of that program, as it now exists," Wasby continued, " is the exchange between the Congressional Fellows and the Canadian Parliamentary Interns-a program that has attracted my support because of the separate opportunity I have had to teach on two occasions in Canada. I would like to see the exchange continue and flourish.

"Because of my Congressional Fellowship experience," Wasby stated, "I am making a gift of securities- $\$ 2,500$ this year and an equal amount in each of the next three years-to the American Political Science Association to be used as part of a challenge to others, both former Congressional Fellows, other individuals, and public and private sector entities, to make contributions for Congressional Fellows-Canadian Parliamentary Interns Exchange. I make this gift in honor of our special guest, former Representative Lee Hamilton, for his long, accomplished career and for his firm support of the Congressional Fellowship Program. ... May the Congressional Fellowship Program long prosper."

The evening's events highlighted the fact that, for its 48 years of existence, CFP has flourished thanks to the support of its good friends and alumni. Let's hope in the months ahead that the more than 1700 former Congressional Fellows can match Lee Hamilton's abiding interest in international relations and Steve Wasby's generosity.

\section{$\begin{array}{lllllllllll}P & R & O & C & E & E & D & I & N & G & S\end{array}$ Political Research Online}

http://pro.harvard.edu http://pro.harvard.edu http://pro.harvard.edu

Nearly 1,300 Papers from APSA's 96th Annual Meeting are available on PROceedings, the online searchable collection of APSA Annual Meeting Papers and abstracts through August 2001. ROceedings features numerous subfields of political science, making it a valuable resource for research and teaching.

PROceedings aims to disseminate political science research more broadly and directly, to continue the scholarly exchange of the Annual Meetings beyond their setting, to encourage the instructional use of research and to facilitate individual and library access to Annual Meeting papers.

PROceedings is a collaborative effort of the American Poltical Science Association, the Harvard University Library, and The College of New Jersey, under the direction of William J. Ball. PROceedings was introduced at the 1997 Annual Meeting and is supported by a grant from the Andrew W. Mellon Foundation.

If you have questions about, and or suggestions for, PROceedings, please write to proceedings@apsanet.org.

\section{http://pro.harvard.edu}

